\title{
Grammar Learning At Tertiary Level In Indonesia: A Curriculum Development of Genre-Task Based Approach
}

\author{
Wuwuh Asrining Surasmi1,a, Suparti1,b, Eka Fadilah2,c \\ 1 Universitas Terbuka Surabaya , Indonesia \\ 2Unversitas Widya Kartika Surabaya, Indonesia \\ a wuwuh@ecampus.ut.ac.id; b suparati@ecampus.ut.ac.id; c mref3k4@gmail.com \\ ${ }^{*}$ Corresponding Author \\ Whatsapp Number: [087854313129]
}

How to Cite : Surasmi, W., A., Suparti, S., Fadilah, E. (2020). Grammar Learning At Tertiary Level In Indonesia: A Curriculum Development Of Genre-Task Based Approach. International Journal for Educational and Vocational Studies, 2 (1), 41-49. DOI: https://doi.org/10.29103/ijevs.v2i1.1945

\section{ARTICLE HISTORY}

Received: 13 November 2019

Revised: 28 November 2019

Accepted: 4 January 2020

\section{KEYWORDS}

Grammar Learning;

Genre-Task Based Approach;

Curriculum Development;

\section{ABSTRACT}

This article explores the grammar learning in two influential English language teaching (ELT) curriculum approaches to tertiary level and the potential approach to interweave them. The two prominent approaches shaping language learning in Indonesia are communicative language teaching (CLT) specified in Task-based Instruction and Genre approaches rooted in Systemic Functional Language (SFL). Given the various curriculum which comes and goes, bringing together with miscellaneous methods or approaches, it is urgently needed to adapt rather than adopt the wholesale methods or approaches by making the nexus between those two aproaches to fit the context. This article aims at revisiting creative and innovative grammar teaching and learning at tertiary educational level. We elucidate how those approaches foster English as a Foreign Language (EFL), notably, how grammar should be learnt and assessed through them.

This is an open access article under the CC-BY-SA license.

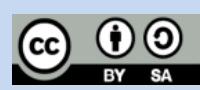

\section{INTRODUCTION}

Indonesian English teaching curriculum has shifted and undergone some revisions starting from grammar-translation Method to Communicative Language Teaching (CLT) and Genre-based approach (Fadilah, 2018a). The two latter curriculum approaches have been still maintained until to date as both intended and enacted curriculum approaches (Graves \& Garton, 2017). While the former entails 'understanding of what is to be learnt and how', the latter denotes how such an understanding is 'enacted (or not) in the classsroom (p.442). As Indonesian is accustomed to structural syllabus (Ariatna, 2016), grammar becomes a pivotal concern to be integrated in both approaches. How grammar should be learnt and assessed becomes a prominet issue to be discussed. Besides, how to integrate the two curriculum approaches in which grammar is attached becomes a potential approach instead of in isolation.

Grammar constitutes a fundamental aspect of a language in which "without grammar, language does not exist" (Nassaji \& Fotos, 2011, p. 1) since it is "the heart of language use, whether this involves speaking, listening, reading, or writing" (Purpura, 2004, p.ix). Likewise, as a central processing unit of language to entail meaning-making, it is natural that "systems of sound and of writing through which this meanings are expressed should reflect the structural arrangement of the grammar" (Halliday \& Matthiesen, 2004, p.21). The rise of miscellaneous grammatical approaches explicated by some methods i.e., Audio-Lingual Method deals with the best assumption that major problems in language teaching i.e., English as a Foreign Language was exclusively relied on the lack of grammatical competence. In its implementation, however, many SLA/EFL researchers and scholars have questioned the efficacy of the foregoing approaches. Consulting the research on form-meaning mapping and meaning-making instructions, it was cited that none of grammar teaching by presenting learners with rules and examples followed by discrete matches develop the learners' language (Nassaji \& Fotos, 2011). Indeed, there is a gap between pedagogical grammar rules and theoretical constructs in linguistics, however, grammar teaching through rules carried out deductively and inductively constitutes a common classroom practices persisted by 
language teachers (Larsen-Freeman, 2015).

\section{METHODS}

Larsen-Freeman (2003 cited in Larsen-Freeman, 2015) coined term "grammaring" to challenge how grammar learning, featuring a static system with a finite number of rules, gradually evolves into dynamic system (thinking grammar as a skill rather than a finite number of rules to create new form to make new meaning). Furthermore, Larsen-Freeman (2016) maintains that the rule exposures are by no means of teaching grammatical rules as explicated in the traditional method, but stimulating the learners to provide the reasons why such form is such the way 'Grammarring'. Accordingly, the knowledge of the grammatical form, meaning, and use is conceived to prime the learners when accomplishing the tasks provided through a transfer from the grammatical knowledge (what) turned into its implementation (how).

On the other hand, rooted from Systemic Functional Language (SFL) theory, Halliday and Matthiesen (2004) put forward notion "lexicogrammar" as two poles of a single continuum which go together as the powerhouse where meanings are created. Halliday and Matthiesen pinpoint that grammar interfaces with what goes on the outside of language in which we use language to make sense of our experience as well as to carry out the interaction with other people. In a similar vein, Fontaine (2014) maintains "functional grammatical analysis" which explicates how a language works for lots different reasons, thereby "if we want to work with language, we need a way to talk about it, and we need a way to identify the bits and pieces that it involves" (p.1). In other words, the ability to recognize language functions and structures is inseparable. The former explicates what language is doing (for the speaker), while the latter signifies how language is formed, shaped, and specifically organized.

The present article features how grammar learning is carried out in the English as a Foreign Language (EFL) context at tertiary level. Given the considerable novel research findings illuminating the ample evidences of language learning theories and practices shaping grammatical methods and approaches, it is necessarily to re-conceive how such innovative and creative findings contribute to the pedagogical practices and curricular development. As Graves and Garton (2017) put forward that the novel approaches in grammar teaching is by no means to endorse a particular method or approach, but rather how grammar comes at playing role in those approaches i.e., CLT, and genre, therefore we need to see them as 'the potential to interweave' the two appraoches.(p. 442 italic added).

We embark with some notions in regard to how grammar is well-learnt through task-based instruction, genre-based, and the nexus between them followed by some research findings favoring them which are by no mean exhaustive. We also present some novel grammar assessments reported by some EFL/SLA researchers which are expected to illuminate curriculum development. Later, recommendation is explicated as further discussions to be made to shed more light on grammar learning at tertiary level. As Nation and Macalister (2010) put forward some considerations which need to be taken into account prior to developing a curriculum embracing (1) principles, needs, and environment as outer circles, and (2) content and sequencing, format and presentation, and monitoring and assessing as inner circles. The former circles "involve practical and theoretical considerations that will have a major effect in guiding the actual process of course production" (p.1), while the latter circles comprise content and sequencing which represents course content matters to be included, format and presentation representing teaching methods to be carried out, and monitoring and assessing referring to testing and assessment to be conducted.

\subsection{What task is}

Prior to further discussion, we raise the term task due to its miscellaneous definitions proposed. It is likely not too overwhelmingly to say that in the level of teaching practices, teachers do not understand well the notion of task. The considerable evidences were taken from Asian contexts; notably found in China, Hongkong, and Indonesia, in which the teachers found difficulties to understand what task is (see e.g., Littlewood, 2007). In the similar vein, Zheng and Borg (2014) revealed that task was conceived narrowly and understood as providing learners with speaking activities in a pair or group by dismissing grammar teaching. More recently, Erlam (2016), through a year-long professional development program aiming at equipping teachers' professionalism, documented that teachers did not understand some aspects of task. Although teachers are able to explain some concepts in conjunction with the task criteria, but it left to a caveat that they are still "not sure what a task is" (Erlam, 2016, p.1).

We cannot discuss detailed task definitions here, but, Samuda and Bygate (2008) provide those embracing more than a dozen task definitions proposed by SLA researchers and scholars. Taken together, Samuda and Bygate operationalize task as "a holistic activity which engages language use in order to achieve some non-linguistic outcome while meeting a linguistic challenge, with the overall aim of promoting language learning, through process or product or both" (p.69). While, Long (2015) defines task as "the real world activities people think of when planning, conducting, or recalling their day" (p.6). Likewise, Ellis and Shintani (2013, p.135) elaborated a detail concept of task falling into four criteria: (1) the primary focus should be on meaning by invoking learners to encode and decode messages, not focusing on linguistic form, (2) there should be some kind of gap as media to convey information, to express an opinion or to infer meaning, (3) learners should largely rely on their own resources (linguistic and non-linguistic) to complete the task activity, and (4) there is a clearly defined outcome other than the use language by putting language as the means for achieving the outcome, not as an end in its own 
right.

\subsection{Task-based Instruction}

Understanding the notion of task (what) is important as a basis for teachers how to actualize task as pedagogy in their daily teaching practices. In doing so, the next strand should be (How) to contextualize task instruction - as a Western origin product in ESL contexts, could be best realized and practiced in the EFL classroom contexts, but Shehadeh and Coombi's (2012) compelling book-chapter elucidates the latter.

Littlewood (2014) explicates that the realization of CLT falls into two strands: strong and weak CLT. The former denotes the maintenance of the authenticity of "taskness" in the classroom teaching practices, Task Based Language Teaching (TBLT), while the latter invokes taskness into pedagogic and contents - Task Supported Language Teaching (TSLT). In TBLT, task is conceived as a sole basis of the syllabus and material design aiming at maintaining the SLA/cognitive underpinnings by putting language communication as a main focus. On the other hand, TSLT, commonly seen in EFL setting, puts tasks as adjunct of classroom communication activities carried out in a more explicit structure-based syllabus. Shehadeh and Coombi (2012), together with other researchers, provide empirical evidences how Task-based instruction is carried out in EFL setting, but they do not provide a clear distinction about TBLT and TSLT throughout their book-chapter. Furthermore, Li, Ellis, and Zhu (2016) put forward TBLT as a pure communication activity in which "there is no explicit instruction" to the target of linguistic features, while TSLT “there is" (p.207).

Ellis (2017), on the other hand, maintains task types should embody both input-based task and output-based task. The former fits the beginners/low proficiency learners who are accustomed a more traditional, structural approach with a large class, while the latter is well-suited to higher/advanced learners as opportunities to produce language. Detailed examples of activity of input and output task based are elucidated by Nassaji and Fotos (2011) who rigorously explicates the theoretical, empirical, and pedagogical task performances in the classroom context. For instance, input-based task on grammar focus could be actualized through processing instruction, textual enhancement, and discourse. Additionally, output-based tasks on grammar focus might be carried out through collaborative output task - dictogloss, reconstruction cloze tasks, text-editing tasks, and collaborative jigsaw tasks. Those input and output task types encompass focused and unfocused tasks in which they have little attention from researchers.

Fadilah (2018b) provides evidence that focused task is more effective than unfocused one for Indonesian university learners on the acquisition of learner's grammatical feature, English comparison. Shintani (2012) reported the efficacy of input task based instruction, Three-Listen-and-do tasks (e.g., listen, do, and perform), on learners' grammatical development, plural -s. While, Spada, Jessop, Suzuki, Tomita, \& Valeo (2014) reveal that explicit output tasks-based instruction group outperforms the implicit one on learners' acquisition of be passive sentence construction. Furthermore, Li, Ellis, and Zhu (2016) investigated the efficacy of TBLT vs.TSLT in the form of dictogloss (listen, take note, discuss, and perform) tasks. They conclude that TSLT group outperformed TBLT and control groups. In other words, the more explicit the treatment, the greater the effect.

\section{RESULTS AND DISCUSSION}

\section{Results}

Halliday (1994) defines SFL as a theory of language that aims to "construct a grammar for purposes of text analysis, one that would make it possible to say sensible and useful things about any text, spoken or written, in modern English" (p.xv). For Halliday, grammar is understood as connecting lexicon and grammar called as lexico-grammar which is interpreted by meaning-making through particular wording choices (Byrnes, et al., 2010). In the process of meaning-making, it is explicated that wording serves as the grammatical base for lexicogrammatical construction, and eventually construes the meaning. Likewise, Halliday and Matthiesen (2004) propose two steps of meaning-making interface: First, the interface experience and interpersonal are transformed into meaning (semantic stratum). Second, the meaning is further transformed into wording (lexico-grammar stratum). Furthermore, the scope of grammar rooted in SFL is extended "from a rather narrowly conceived focus on morphosyntax features at the clause level to an elaborate system of interlocking linguistic choices of patterns of textual organization of specific situational and cultural contexts" (Liamkina \& Ryshina-Pankova, 2012, p. 271).

The notion Grammatical Metaphor (GM) was initially seen as variation of words that expresses meaning, as Halliday (1994, p.321) put forward "a word is said to be used with a transferred meaning". In this notion, a word (lexeme) which construes a literal meaning can be transferred into metaphorical meaning. Later on, the term literal was claimed to be no longer appropriate, by putting forward congruent realization as an important role which explicates a variation in the expression of a given meaning, rather than variation in the meaning of a given expression (Simon-Vandenbergen, Taverniers \& Ravelli, 2003). For Halliday and his associates, lexical selection as presented as literal meaning is just one aspect of lexicogrammatical selection and therefore metaphorical variation is best conceived to lexicogrammar rather than simply lexis. Given an example: expression flood (one lexeme) could be expressed as a moving mass of water (literal meaning) and a moving mass of feeling or rhetoric (metaphorical meaning). It is also cited to be hard to find alternative expressions of a given meaning which only differ from each other in one lexeme, flood. Furthermore, Halliday put forward another example: many people 
protested (one meaning) could be expressed as a large number of protests (congruent form) and a flood of protests (non-congruent/metaphorical form). It also elucidates that a flood of protests constitutes different grammatical configurations such as protests came in in large quantities (adding preposisitional phrase) and very many people protested (the noun protests is now represented by a verb protested). This is what Halliday claims as "grammatical metaphor" (ibid, p.7).

Lin (2016) put forward GM as linking to nominalization in which "nominalized word or group functions as if it were grammatical participant" (p.51). Adapting Halliday and Martin's model of GM (see Figure 1 ), Lin pinpoints that the verb moves (original clause) functioning as a process is shifted into nominalization as motion functioning as a thing in the nominal group. likewise, Byrnes (2009) argues that such a shifting - a movement from process or quality to thing - "is a significant expansion of the semantic resources for construing experience in all functional environments, but particularly in the ideational and the textual functions" (p.52). For instance, sentences we hope that peace will soon be restored $\rightarrow$ Our hope for an early restoration of peace ...explicate verbs (hope, be restored) as a process are realized metaphorically as a thing nouns (hope, restoration), while a participant (we) and (peace) are realized as the qualifying expansion of a thing (our and restoration of peace); and an adverbial (soon) shifts into an epithet (early). However, It takes a long process to figure out such a shifting in which adult phase referring to the advanced literacy suits to GM construction (Christie, 2012).

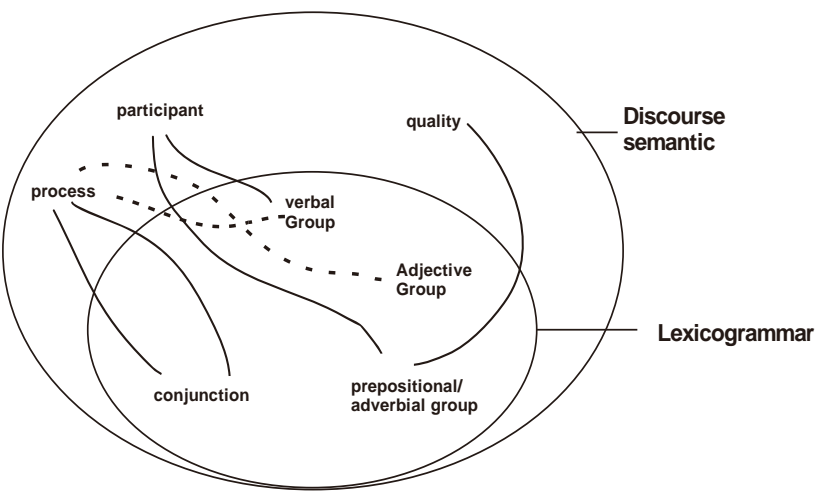

Figure 1. Realization And Transcategorization Of Incongruent Form Of Grammatical Metaphor (Fadilah \& Anugerahwati, 2019, p.135)

Colombi (2006) reported that GM enables learners of Spanish to construct texts by moving from a description to interpretation of reality in which putting "nominalization as a central grammatical metaphor" (p.152). Specifically, learners are treated by using GM approach in removing actors (agents of actions), turning actions into things, and creating conceptual objects. In the similar vein, Byrnes (2009) conducted a longitudinal study by tracing the development of GM (interconnections between SFL as a theory of language and GM as a semogenic process central to the theory) on the Germany University learners with the movement from more personal narrative to more public argumentative language tasks. Her findings highlights that Intermediate writers' use of GM in writing tasks indicates more or less stable in the average numbers of clauses, while Advanced writers' GM use remarkably jumps by more than triples during one semester. Likewise, Ryshina-Pankova (2010) reveals that providing FL learners with GM, as a phenomenon of trans-categorization, in various Genres enables Germany learners to capture different levels of FL acquisition in which nouns can be encoded in terms of processes (typically realized by verbs), attributes (typically realized by adjectives), and/or whole propositions (typically realized by sentences). Additionally, it is also claimed that the roles and functions of GM can enhance "the ability of the writers to construct a logical argument or persuasive evaluation" (p.181). Based on her depth-analysis it is cited that GM functions to provide a powerful contributor to the coherence and cohesion of texts, to construct evaluation and argumentation, and to evaluate it

\subsection{Genre based}

Genre, rooted in SFL theory, has been widely put into practice in Australian educational context. By positing language as a semiotic system, it embraces three kinds of main meaning: experiential, interpersonal, and textual (Halliday \& Matthiessen, 2004). Furthermore, SFL contextualizes language on the nexus between the meaning being made in a particular context and linguistic resources which evolve to realize those meanings (Christie \& Derewianka, 2008). First, the notion of context encompasses two levels: the cultural context and the situational context. The former refers to genres as a social process for achieving purposes within the culture, while the latter explicates registers which embrace contextual variables of tenor (what is going on?), tenor (who is involved?), and mode (what role is language playing) in which the combination of the three refer to register. Second, the term linguistic resources explicates language system cluster called metafunctions: ideational (language use for constituting our experience and any aspects related to it), interpersonal (language use for interacting with others), and textual (language use for constructing textual coherence and cohesiveness). Jones and Lock (2011) put forward presenting grammar in context that is reconstructing the genre with reference to the features of the situation in which the genre was produced (situational context). Taken together, by presenting grammar to learners in context, it will help them how grammar works within context. The ultimate goal of language is how we use it for particular purpose which serves to function embodying the context in which the user as language speaker uses either consciously or unconsciously in which "understanding how language works means understanding how grammar works" (Fontaine, 2011, p.7). 
Emilia and Hamied (2015) investigated students-teachers' awareness on argumentative writing development through three-text focuses: Exposition, Discussion, and Response to Literary Works. They reveal that genre-approach assists learners' writing development explicated in learners' sample of writing. However, in another study, Aunurrahman, Hamied, and Emilia (2017) found inversed finding. Encompassing learners into low, medium, and high levels of writing proficiency, they reveal that the learners had less critical thinking derived from their argumentative writing samples. Additionally, learners had some limitation in developing their writing skills in terms of grammar, convention, lexical choices, and cohesive devices of conjunction. Therefore, they went on suggesting and echoing explicit teaching and cooperative learnings to resolve such problems.

\section{Discussion}

Byrnes, Crane, Maxim, and Sprang (2006) coined the nexus between task and text (literacy) into curricular terms. They elucidated that tasks need to be expanded theoretically and empirically towards other issues in conjunction with literacy and textuality rather than primarily relying upon psycholinguistic and sentence-oriented consideration. So far, the interwoven between tasks and text seem to be taken separately, instead of juxtaposed process of language learning. It might be the nature of the two approaches in which task is seen as "a strong interactionist, phsycolinguistically focused, and language processing-oriented stance" (Byrnes, 2014, p.236), while genre, derived from SFL theory, is conceived as "much more explicit social orientation" (Ortega, 2009, p. 234). Additionally, Norris (2009) advocates the nexus between text (genre) and task as a potential syllabi in both spoken and primarily written skills. The distinction between spoken and written language refers to the lens of grammatical intricacy and lexical density. It is conceived that spoken language is more complex registerial form in terms of grammatical intricacy, while written language has low grammatical intricacy but high lexical density.

Byrnes and Manchon (2014) criticize the overwhelming focus of TBLT research on oral modality, while written modality focus is under-researched. In a similar vein, East (2017, p. 419) alleged that "TBLT is all about speaking" by devaluing grammar learning. Byrnes, Maxim, and Norris (2010) provide a groundwork theory for balancing the focus between FL oral abilities and writing interest for collegiate students. Byrnes et al., (2010) endorse a curriculum project "Developing Multiple Literacies", adopting a literacy and genre-based approaches and evoke the curriculum developers to prioritize students' literacies development and textual thinking (Paesani, 2018). Such a project is claimed to provide robust evidence of literacy, especially learners' writing skill through text-based teaching and learning (Paesani, 2018; Ryshina-Pankova, 2010). Furthermore, textual thinking is presented by elaborating text as
Multimodal texts combining oral and written texts invoking images, gestures, hypertext, and the like (Paesani, 2018).

Yasuda (2017) initiates the nexus of genre and task-based research focusing on learners' lexicogrammatical awareness in making meaning incorporated by summary writing tasks. It is also claimed to juxtapose with Halliday's (1996 cited in Yasuda, 2017) notion re-meaning ability - the ability to state the original meaning differently from the congruent form on the basis of the genre's demand - in which GM underlies. Initially, he found that learners were difficult to specify grammatical rules or conventions they believed to be an effective way on their writing tasks. In fact, the learners only made a copy in their summary based on the texts provided. In the subsequent tasks, Yasuda discovered that the learners grew to a better understanding when "they shifted from a content-oriented approach (e.g., extracting the gist) to a more language-oriented one (e.g., restating others' ideas; using reporting verbs)" (p. 597). Additionally, the finding postulates that the use of GM, in terms both occurrences and functions, enables learners to write more rhetorically effective and coherently structured in which learners are conceived to develop metalanguage which enable them to distance themselves from the model of text to appropriate lexicogrammatical choices and patterns.

\section{Grammar in curriculum development}

Long (2016) claims that grammar teaching remains necessary in designing Task-based syllabus/curriculum, but it should be made implicitly for not disturbing the flows of communication through implicit corrective feedback, recast, that becomes mediating supervision on learners' sentence deviances during task performances. For Long, some steps and processes need to be taken prior to designing task syllabus: need analysis, target tasks, and pedagogic tasks. In a similar vein, Macalister (2011) advocates need analysis comprising into lacks, wants, and necessities. Specifically, Macalister provides concise illustration on them, for instance, learners who need to be able to write effectively within an academic environment is categorized as learners' necessities despite no prior need analysis, while learners who want to write native-like writing, but encountering environmental constraints, it is wants. While, lacks can be seen from learners' samples or proficiency i.e., writing which indicates their insufficient language skill for success.

Byrnes et al. (2006) provided a concise description of the genre-task based curriculum in both spoken and written modes. For instance, writing genre-task curriculum ranges from Level I (e.g., personal letters, postcard) to Level IV (e.g., letter to journal editor, journalistic report). Similarly, speaking genre-task curriculum embodies subsequent conversational levels ranging from Level I (e.g., monologic presentation to classmates, informal conversation with friends) to Level IV (e.g., panel discussion, formal lecture). Paesani (2018) 
contends that existing research focuses only on learners' linguistic dimension of literacy and cognitive development, but interplaying linguistic, cognitive, sociocognitive, and sociocultural dimensions research remains scant. Thus, Interfacing genre, explicating learners' literacy, and task is claimed to meet such dimensions (Yasuda, 2017). In the similar vein, Chappel (2014) explicates a framework in regard to genre-task based curriculum realization. For instance, in lesson Travel Planning and regrets encompasses a range of modes and genres, that is grammar focus (past tenses, past modals), discourse (retelling past events and actions expressing regret about past events), oral texts (recounting recent travel holiday), and written texts (reading about travel experiences and regrets note-taking and note-making). Those genres are then integrated in a subsequent task model: task orientation, task specification, task collaboration, and task deconstruction.

\section{Grammar assessment}

Traditionally, learners' grammar knowledge was assessed by typically employing discrete-point items of testing such as multiple-choice questions, fill-in-the-blanks, sentence completion, error analysis, etc., The most recent TOEFL testing i.e., iBT requires integrated skills in which grammatical knowledge is assessed holistically through speaking and writing skills, thus, it is not necessarily separating section that deals with structure explicitly. However, it is conceivably difficult to sort out learners' ability in such skills whether their lack competence of those skills are resulted from the lack of grammatical knowledge or not (Larsen-Freeman, 2011). In other words, discrete point items and integrative test assessment of grammar represent different approaches to grammar assessment by considering their ultimate goal.

Purpura (2004) suggests that assessing grammar knowledge should consider the interaction between grammatical knowledge and pragmatic knowledge. The former refers to terms of a range of linguistic forms (e.g., -s affix; word order), while the latter constitutes meanings associated with forms, either individually (e.g., plurality with a noun) or collectively (e.g., the overall literal meaning of the utterance). Furthermore, Purpura (2012) put forward a model of assessing grammar by taking together the grammatical form types associated with semantic meaning and a range of possible pragmatic meaning. For instance, assessing grammar in lexical forms (e.g., different from, similar to) or cohesive meanings (e.g., therefore, in addition to, however), or semantic meaning (e.g., ergative verbs used in middle sentences differ from passive sentences). The example of the latter the car parks well belongs to middle sentence in which it is in an active sentence form but passive form meaning. Furthermore, incorporating grammar with pragmatic knowledge might be implemented by integrating the test takers' knowledge (grammar forms and semantic meanings) with other internal factors (e.g., topical knowledge, sociocognitive ability, and personal attributes) by interweaving test takers' grammar ability, used, and knowledge. In doing the latter test, Purpura suggests to use integrated skills. For instance, in speaking test, the test takers are provided with some conversational domains: (1) the social-interpersonal (e.g., having a conversation in a café), (2) the social-transactional (e.g., resolving a course registration problem), (3) the academic (e.g., listening to a lecture), and (4) the professional (e.g., making a conference presentation).

Larsen-Freeman (2011) recommended grammar assessment to not be only skewed in academic (standard) grammar knowledge, but also spoken grammar. She further suggests that Corpus linguistic provides domains of such a knowledge. Likewise, Frankenberg-Garcia (2012) strongly advocates the rising teachers' awareness of corpora. Corpus (e.g., COCA, BNC) provide millions of words ranging from academic to spoken grammar. For instance, asking the learners to differentiate particle use congratulations on, congratulations to, and congratulations from followed by questions why such forms are different and in which occasions to use.

In the similar vein, Romer (2017) explicates how corpora and corpus-analytic techniques in conceptualizing lexico-grammar in speaking assessment in which the assessment focuses solely on spoken lexis and grammar considered as a unit instead of pronunciation, speech rate, intonation, or intelligibility. The data were taken from the largest freely available English speech corpora on 1.8-million-word Michigan Corpus of Academic Spoken English (MICASE) and 10-million word spoken component of the British National Corpus (BNC), capturing authentic spoken discourse ranging from academic settings to informal, spontaneous conversations. To assess the representation of current lexico-grammatical knowledge use in speaking test, rating scales were applied by relying on three high-stakes speaking tests: TOEFL iBT, IELTS, and CaMLA (Cambridge Michigan Language Assessments). The results postulate two-folds: (a) spoken language used is dominated by phraseological items which suggest interrelatedness and intersection of lexis and grammar as inseparable assessment, thus (2) providing one score on lexico-grammar instead of two separate ones, which is perceived to be difficult by raters, facilitates the practice of scoring tests.

\section{CONCLUSION}

Hlas (2018) put forward "A curious truism is that innovations always lead the field long before the results, impacts, and implications of them can be understood" (p.1 italic added). Given the miscellany constructs of tasks and research findings aforementioned, we put forward some considerations to be made in developing innovative and creative curriculum at Indonesian tertiary level context. First, such miscellanies should be seen as a "nutrients" (Lyster, Sato, \& Saito, 2013) for teachers to use various 
teaching approaches. As Canagarajah (2014) puts forward the success in English learning does not refer to a single norm, but rather "adopt context and interaction specific communication practices that help learners to achieve intelligibility" (p.769). It is by no means of adopting and adhering the wholesale of a single method by devaluing the others, but rather seeking the potential interface interweaving one approach to another to fit the context (Bax, 2003) in which the EFL/ESL teaching is carried out.

Furthermore, Fadilah (2018a) suggests to adapt rather than to adopt the solely single approach or method to fit the context. The lack competence of teacher pedagogic (Widodo, 2016) could be likely resolved by, but not limited to, providing teachers with intensive and extensive school based, collaborative professional development to "connect theory, practice, and students outcome" (Ariatna, 2016, p.7) which could also support the teachers to evoke teachers' belief (derived from the past experiences) and practices (derived from the classroom through professional program to meet them i.e., TEFLIN in which teachers share their classroom practices with colleagues, theorists and researchers, thus giving teachers the opportunity "to theorize from their practice and practice what they theorize" (Kumaravadivelu, 2006, p.59). It might be one of the ways to bridge teachers' belief although, in many cases, they found inconsistency of research findings perpetuate. Benson (2017 borrowing a Berger's metaphor) put forward "Ways of seeing" the people citing that that there has been much discussion of the ways theoretical choices shaping methodological choices, however, there is less consideration how research methodologies shapes theory. It also elucidates how we perceive the learners in which we place them under the various research methodologies.

Second, Preparing pre-service teachers by providing them with miscellaneous, innovative, and creative learning approaches benefit those to apply such approaches as no-size-fits-all when they come at play in teaching experiences as a novice teacher. Indeed, treating English as foreign language in Indonesian context undergoes "lengthy and complex process" due to encountering "learning new language, new culture, and the way of thinking and doing" (Widiati, Suryati, \& Hayati, 2017, p.621). Therefore, there should be an endeavor process of "learning to teach, learning teaching, and just learning" (Larsen-Freeman, 2017, p. 435 italic added).

Third, longitudinal study and in-depth analysis are urgently required to investigate such innovations to shed more light on language teaching and learning in Indonesian context. Such analysis might be initiated by investigating the guiding tools used in the classroom such as foreign/second language planning, instruction, and assessment which are still getting scant attentions from the researchers (Larsen-Freeman \& Tedick, 2016 as cited in Hlas, 2018).
In sum, we conceive that Genre-task based accommodates grammar learning as innovative and creative approaches to develop curriculum at Indonesian tertiary context. It is necessarily to conceive that the nature of genre assists learners' development of literacy and writing. Additionally, it is urgently needed to provide a variety of texts (genres) for university learners as their skills to develop their critical thinking generally as well as prepare them to their thesis. For instance, the various genres: exposition, narration, recount, description, and argumentation can assist them on their thesis writing process by actualizing them in any parts of thesis chapters: Introduction, review of literature, method, finding, discussion, and conclusion. While, task based instruction is aimed at, but not limited to, learners' speaking ability. Thereby, the interplay of both might spur learners' grammatical knowledge and development.

\section{REFERENCES}

Ariatna (2016). The need for maintaining CLT in Indonesia. TESOL Journal, 7(3), 1-23.

Aunurrahman, Hamied, F.,A., \& Emilia, E. (2017). Exploring the tertiary EFL students' academic writing competencies. Indonesian Journal of Applied Linguistic, 7 (1), $72-79$

Bax, S. (2003). The end of CLT: A context approach to language teaching. ELT Journal, 57 (3), 278-287

Benson, P. (2017). Ways of seeing: The individual and the social in applied linguistics research methodologies. Language Teaching, 1-11. doi.:10.1017/S0261444817000234

Byrnes, H. \& Manchon, R. (2014). Task-based language learning: Insights from and for L2 writing: An introduction. In H. Byrnes \& R. Manchon (Eds.), Task based language learning: Insights from and for L2 writing (pp. 1-26). Amsterdam, the Netherlands: John Benjamins.

Byrnes, H., Maxim, H. H., \& Norris, J. M. (2010). Realizing advanced foreign language writing development in collegiate education: Curricular design, pedagogy, assessment. Modern Language Journal, 94 (Supplement).

Byrnes, H. (2009). Emergent L2 German writing ability in a curricular context: A longitudinal study of grammatical metaphor. Linguistics and Education, 20, $50-66$.

Byrnes, H., Crane, C., Maxim, H. H., \& Sprang, K. A. (2006). Taking text to task: Issues and choices in curriculum construction. ITL-International Journal of Applied Linguistics, 15 (2), 85 -109.

Canagarajah, A. S. (2014). In search of a new paradigm for teaching English as an international language. TESOL Journal, 5, 767-785.

Chappell, P. (2014). Group work in the English language curriculum: Sociocultural and ecological perspectives on 
second language classroom learning. New York: Palgrave Macmillan.

Christie, F. (2012). Language learning through the school years: A functional perspective. Malden, MA: Wiley \& Sons.

Christie, F. \& Derewianka, B. (2008). School discourse: Learning to write across the year of schooling. London: Continuum.

Colombi, M. C. (2006). Grammatical metaphor: Academic language development in Latino students of Spanish. In H. Byrnes (Eds.), Advanced language learning: The contribution of Halliday and Vygotsky (pp. 147-163). London, England: Continuum.

East, M. (2017). Research into practice: The task-based approach to instructed second language acquisition. Language Teaching, 50 (3), 412-424.

Ellis, R. (2017). Position paper: Moving task-based language teaching forward. Language Teaching, 50 (4), 507-526.

Ellis, R., \& Shintani, N. (2013). Exploring Language Pedagogy through Second Language Acquisition Research. London, England: Routledge.

Ellis, R. (2009). Task-based language teaching: Sorting out the misunderstandings. International Journal of Applied Linguistics, 19, 221-246.

Ellis, R. (2003). Task-based language learning and teaching. Oxford, England: Oxford University Press.

Emilia, E. \& Hamied, F., A. (2015). Systemic functional linguistic genre pedagogy (SFL GP) in a tertiary EFL writing context in Indonesia. TEFLIN Journal, 26 (2), 155-180.

Erlam, R. (2016). I'm still not sure what a task is: Teachers designing language tasks. Language Teaching Research, 20, 279-299.

Fadilah, E., \& Anugerahwati, M. (2019). Grammatical metaphor at tertiary level: Rise, development, and implications revisited. Argentinian Journal of Applied Linguistics, 7 (1), 131-143.

Fadilah, E. (2018a). Oral corrective feedback on students' grammatical accuracy and willingness to communicate in EFL classroom: the effects of focused and unfocused prompts. The Asian EFL Journal, 20 (4), 57-85.

Fadilah, E. (2018b). Rethinking the maintenance of CLT in Indonesia: A response to: Ariatna's (Vol. 7, No. 2, 2016) "The Need for Maintaining CLT in Indonesia". TESOL Journal, 9 (1), 224-236.doi: 10.1002/tesj.341

Fontaine, L. (2014). Analysing English grammar: A systemic functional introduction. New York: Cambridge University Press.

Frankenberg-Garcia, A. (2012). Raising teachers' awareness of corpora. Language Teaching, 45 (4), 475489.

Graves, K., \& Garton, S. (2017). An analysis of three curriculum approaches to teaching English in public-sector schools. Language Teaching, 50, 441-482.

Halliday, M. A. K. \& C. M. Matthiessen (2004). An introduction to functional grammar (3rd edn.). London: Arnold.

Halliday, M.A.K. (1994). Introduction to Functional Grammar (2nd edition). London: Arnold.

Hlas, A.,C. (2018). Grand challenges and great potentialin foreign language teaching and learning. Foreign Language Annals, 51, 46-54.

Jones, R.H., \& Lock, G. (2011). Functional grammar in the ESL classroom: Noticing, exploring, and practicing. New York: Palgrave Macmillan

Kumaravadivelu, B. (2006). Understanding language teaching: From method to post-method. Mahwah, NJ: Lawrence Erlbaum.

Larsen-Freeman, D. (2017). Just Learning. Language Teaching, 50 (3), 425-437.

Larsen-Freeman, D. (2015). Saying what we mean: Making the case for second language acquisition to become second language development. Language Teaching, 48 (4), 491-505.

Larsen-Freeman, D. (2011). Teaching and Testing Grammar. In M. Long, \& C. Doughty (Eds.), Handbook of language teaching (pp. 518-542). Cambridge, MA: Blackwell.

Liamkina, O., \& Ryshina-Pankova, M. (2012). Grammar dilemma: Teaching grammar as a resource for making meaning. Modern Language Journal, 96(2), 270-289.

Li. S., Ellis, R., Zhu, Y. (2016). Task-based versus task-supported language instruction: an experimental study. Annual Review of Applied Linguistic, 36, 205-229.

Lin, A.,M.,Y. (2016). Language across the curriculum \& CLIL in English as an additional language (EAL) contexts: Theory and practice. Singapore: Springer.

Littlewood, W. (2014). Communication-oriented language teaching: Where are we now? Where do we go from here? Language Teaching, 47, 349-362.

Littlewood, W. (2007). Communicative and task-based language teaching in East Asian classrooms. Language Teaching, 40(3), 243-249.

Long, M., H.(2016). In defense of tasks and TBLT: Nonissues and real issues. Annual Review of Applied Linguistics, 36, pp. 5-33.

Long, M., H. (2015). Second language acquisition and task based language teaching. Malden, MA: Wiley-Blackwell.

Lyster, R., K. Saito \& M. Sato (2013).Oral corrective feedback in second language classrooms. Language Teaching 46 (1), 1-40.

Macalister, J. (2011). Refreshing a writing course: the role of evolution. In J. Macalister \& I.S.P. Nation (Ed.), Case studies in language curriculum design: Concepts 
and approaches in action around the world (pp. 114-128). New York: Routledge.

Nassaji, H. \& Fotos, S. (2011). Teaching grammar in second language classrooms: Integrating form focused instruction in communicative context. New York and London: Routledge.

Nation, I.S.P. \& Macalister, J. (2010). Language curriculum design. New York: Routledge

Ortega, L. (2009). Understanding second language acquisition. London, England: Hodder Arnold.

Paesani, K. (2018). Researching literacies and textual thinking in collegiate foreign language programs: Reflections and recommendations. Foreign Language Annals, 51, 129-139.

Purpura, J. E. (2012). Assessment of Grammar. In C. Chapelle (Ed.), the encyclopedia of applied linguistics. Malden, MA: Wiley-Blackwell.

Purpura, J., E. (2004). Assessing grammar. Cambridge, UK: Cambridge University Press.

Romer, U. (2017). Language Assessment And The Inseparability of Lexis And Grammar: Focus On The Construct Of Speaking. Language Testing, 34 (4), 477-492.

Ryshina-Pankova, M. (2010). Toward mastering the discourses of reasoning: Use of grammatical metaphor at advanced levels of foreign language acquisition. Modern Language Journal, 94, 181-197.

Samuda, V. \& M. Bygate (2008). Tasks in second language learning. Basingstoke: Palgrave Macmillan.

Sarandi, H. (2015). Reexamining elicited imitation as a measure of implicit grammatical knowledge and beyond...?. Language Testing, 32(4), 485-501.

Shehadeh, A. \& Coombe, C. (2012). Task-based language teaching in foreign language contexts: Research and implementation. Amsterdam: John Benjamins.

Shintani, N. (2012). Input-based tasks and the acquisition of vocabulary and grammar: A process-product study. Language Teaching Research, 16(2), 253-279.

Simon-Vandenberg, A.M., Taverniers, M. \& Ravelli, L. (2003). Grammatical metaphor. Philadelphia: John Benjamins.

Spada, N., Jessop, L., Suzuki, W., Tomita, Y., \& Valeo. (2014). Isolated and integrated form-focused Instruction: Effects on different types of L2 knowledge. Language Teaching Research, 18, 453-473.

Widiati, U., Suryati, N., \& Hayati, N. (2017). Unraveling the challenges of Indonesian novice teachers of English. Indonesian Journal of Applied Linguistic, 7 (3), 621-629.

Widodo, H. P. (2016). Language policy in practice: Reframing the English language curriculum in the Indonesian secondary education sector. In $\mathrm{R}$. Kirkpatrick (Ed.), English Language Education Policy in Asia (pp. 127-151). Switzerland: Springer.
Yasuda, S, (2017). Toward a framework for linking linguistic knowledge and writing expertise: Interplay between sfl-based genre pedagogy and task-based language teaching. TESOL Quarterly, 51 (3), 576-606.

Zheng, X. \& Borg, S. (2014). Task-based learning and teaching in China: Secondary school teachers' beliefs and practices. Language Teaching Research, 18 (2), $205-221$. 